\title{
MENINGKATKAN DISPOSISI BERPIKIR KREATIF MATEMATIS MELALUI PENDEKATAN APOS
}

Oleh:

\author{
Elda Herlina
}

\author{
STAIN Batusangkar Sumatera Barat \\ herlin_stain@yahoo.co.id
}

\begin{abstract}
Makalah ini membahas tentang disposisi berpikir kreatif matematis, yang meliputi aspekaspek perilaku kreativitas adalah: awareness and sensitivity to problems, memory, fluency, flexibility, originality, self-discipline and persistence, adaptability, intellectual playfulness, humor, nonconformity, tolerance for ambiguity, self confidence, skepticism, dan intelligence. Disposisi berpikir kreatif matematis siswa/mahasiswa terlihat masih rendah. Sikap ini terlihat kurangnya minat siswa/mahasiswa dalam menyelesaikan permasalahan matematika, seperti rendahnya rasa ingin tahu siswa/mahasiswa, kurang imajinatif, tidak berani mengambil resiko, dan lain-lain. Selain itu pentingnya disposisi berpikir kreatif matematis berkaitan dengan pentingnya penguasaan kompetensi matematika untuk kehidupan peserta didik, seperti yang terdapat pada standar kompetensi lulusan oleh pemerintah melalui Permen 23 tahun 2006. Tiga hal dasar yang menjadi pertanyaan dalam makalah ini yaitu: 1. Apa itu disposisi berpikir kreatif matematis? 2. Bagaimana Meningkatkan disposisi berpikir kreatif matematis siswa/mahasiswa?
\end{abstract}

Kata Kunci : Disposisi Berpikir Kreatif Matematis, aksi, proses, objek, skema

This paper discusses the creative mathematical thinking dispositions, which include behavioral aspects of creativity are : awareness and sensitivity to problems , memory, fluency , flexibility , originality , self - discipline and persistence , adaptability , intellectual playfulness , humor, nonconformity, tolerance for ambiguity, self confidence, skepticism , and intelligence. Disposition creative thinking mathematically pupil / student looks still low . This attitude is seen to lack of interest of students / student in solving mathematical problems, such as lack of curiosity of students / college students, less imaginative , did not dare to take risks, and others. Besides the importance of creative thinking dispositions mathematically related to the importance of mastering math competency for life learners , as well as on competency standards by the government through Candy 23 in 2006 . Three basic thing that is in question in this paper are: 1 . What is a creative mathematical thinking dispositions ? 2 . How to Improve students' mathematical dispositions creative thinking / student?

Key words : Disposition of Creative Thinking Mathematically, actions , processes , objects, schemes 


\section{Pendahuluan}

Prestasi pembelajaran di sekolah tidak hanya ditentukan oleh kemampuan kognitif peserta didik, namun juga ditentukan oleh kemampuan afektifnya. Kemampuan afektif yang dimaksud pada makalah ini adalah disposisi berpikir kreatif, yakni kecenderungan seseorang bersikap dan berpikir kreatif. Pengalaman penulis selama mengajar baik di tingkat sekolah menengah maupun perguruan tinggi terlihat bahwa disposisi berpikir kreatif matematis mahasiswa masih terlihat rendah. Hal ini dapat diamati pada sikap peserta didik yang kurang berminat dalam menyelesaikan masalah matematika yang diberikan, seperti rendahnya rasa ingin tahu peserta didik, kurang imajinatif, tidak berani mengambil resiko, tidak mau bertanya apabila ada yang tidak dipahami, dan lain-lain. Padahal disposisi berpikir kreatif ini dapat dilatih dan ditingkatkan dengan merubah paradigm peserta didik dan membiasakan mereka berpikir (habbits of mind).

Salah satu cara yang dapat dilakukan untuk meningkatkan disposisi berpikir kreatif adalah dengan menerapkan pendekatan pembelajaran yang menekankan pada perolehan pengetahuan melalui konstruksi mental, yaitu pendekatan APOS. Menurut Suryadi (2012) konstruksi mental dalam konteks teori APOS adalah terbentuknya aksi, yang direnungkan menjadi proses, selanjutnya dirangkum menjadi objek, objek dapat diuraikan kembali menjadi proses. Aksi, proses, dan objek dapat diorganisasi menjadi suatu skema, yang selanjutnya disingkat menjadi APOS.

\section{Pembahasan}

\subsection{Disposisi Berpikir Kreatif Matematis}

\subsubsection{Berpikir}

Matematika tidak bisa dipisahkan dengan aktivitas berpikir. Menurut Suryadi (2012) walaupun istilah berpikir sudah sangat dikenal luas oleh masyarakat serta prosesnya dilakukan setiap orang, tetapi istilah tersebut sulit didefinisikan secara operasional. Walaupun demikian, para ahli memberikan pandangan tentang makna berpikir sesuai dengan cara pandang yang berbeda, misalnya Sagala (2003) menyatakan bahwa berpikir adalah proses dinamis yang melalui tiga langkah berpikir, yakni: (a) pembentukan pengertian, yaitu melalui proses mendeskripsikan ciri-ciri yang sama, mengabstraksi dan menyisihkan, membuang dan menganggap ciri-ciri yang hakiki; (b) pembentukan pendapat, yaitu pendapat yang dirumuskan secara verbal berupa pendapat menolak, menerima dan mengiyakan dan pendapat asumtif, yaitu mengungkapkan kemungkinan-kemungkinan suatu sifat; dan (c) pembentukan keputusan atau kesimpulan sebagai hasil pekerjaan akal. Sedangkan Peter Reason (dalam Sanjaya: 2010) menyatakan bahwa berpikir (thinking) adalah proses mental seseorang yang lebih dari sekedar mengingat (remembering) dan memahami (comprehending). 
Berdasarkan pendapat di atas, pengertian berpikir pada makalah ini adalah proses mental seseorang yang berfungsi untuk menyelesaikan masalah yang lebih dari sekedar mengingat dan memahami serta melibatkan manipulasi otak sehingga terbentuk representasi mental baru. Kemampuan berpikir seseorang dapat dikembangkan melalui belajar, bertanya terus pada diri sendiri, memiliki keinginan untuk menghasilkan sesuatu yang baru, berkemauan memanfaatkan sesuatu yang ada di sekitar, sehingga menghasilkan sesuatu yang berguna bagi dirinya maupun bagi orang lain. Kemampuan berpikir ini dimungkinkan untuk berkembang karena manusia memiliki rasa ingin tahu yang selalu terus berkembang. Berarti keterampilan berpikir setiap orang akan selalu berkembang dan dapat dipelajari. Depdiknas (2004) menegaskan bahwa salah satu kecakapan hidup (life skill) yang perlu dikembangkan melalui proses pendidikan adalah keterampilan berpikir. Hal ini menunjukkan bahwa seseorang untuk dapat berhasil dalam kehidupannya antara lain ditentukan oleh keterampilan berpikirnya, terutama dalam upaya memecahkan masalah kehidupan yang dihadapinya.

Tingkat berpikir menurut Taksonomi Bloom (dalam Sabandar, 2008) adalah ingatan, pemahaman, aplikasi, analisis, evaluasi, dan kreatifvitas. Tingkat berpikir ini kemudian direvisi kembali oleh Bloom dengan mengelompokkan proses yang digunakan siswa untuk memperoleh pengetahuan terdiri atas dimensi pengetahuan dan proses. Dimensi pengetahuan mencakup pengetahuan faktual, konseptual, prosedural, dan pengetahuan metakognitif. Proses terdiri atas kategori mengingat, memahami, aplikasi, analisis, evaluasi, dan menciptakan. Keterampilan atau kemampuan berpikir yang paling rendah adalah mengingat, misalnya mengingat fakta-fakta dasar ataupun rumus-rumus matematika. Kemampuan ini yang sejak awal umumnya dilatihkan kepada siswa misalnya mengingat $4 \times 4=16,8+4=12$, jumlah ukuran tiga sudut dalam sembarang segitiga adalah 180 derajat, $\log a b=\log$ $a+\log b$, dan sebagainya.

Sekalipun berada pada level rendah dalam kemampuan berpikir, namun peranan mengingat tetap penting, antara lain agar mempermudah dan memperlancar seseorang dalam menyelesaikan suatu masalah. Kemampuan berpikir pada level berikutnya adalah kemampuan memahami atau mengerti konsep-konsep matematika, demikian juga kemampuan untuk mengenal atau menerapkan konsep konsep tersebut dalam mencari penyelesaian terhadap masalah yang dihadapi. Pada umumnya bagi para siswa yang senang dan menyadari pentingnya belajar matematika serta manfaat matematika, tentu mereka perlu dibina agar memiliki kemampuan berpikir tingkat lanjut sehingga mereka mencapai jenjang pengetahuan yang lebih tinggi. Kemampuan pemecahan masalah adalah kemampuan atau kompetensi esensial atau utama dalam mempelajari matematika, yang direkomendasikan untuk dilatihkan serta dimunculkan sejak anak belajar matematika dari Sekolah Dasar sampai seterusnya (NCTM, 2000). Oleh karena itu dibutuhkan kemampuan berpikir matematika siswa untuk memecahkan masalah 
matematika. Sedangkan menurut Marzano, dkk. dalam Suryadi (2012) kemampuan berpikir yang utama mencakup delapan kelompok, yaitu kemampuan memfokuskan, mendapatkan informasi, mengingat, mengorganisasi, menganalisis, menghasilkan, mengintegrasikan, dan mengevaluasi. Selain pengertian berpikir, sebelum membahas tentang disposisi berpikir kreatif matematis perlu dibahas tentang berpikir matematis (mathematical thinking).

\subsubsection{Berpikir Matematis (Mathematical Thinking)}

Berpikir matematis adalah aktivitas yang melibatkan koneksi untuk membangun pemahaman matematika (NCTM, 2000). Selanjutnya Sumarmo (2010) mengemukakan istilah berpikir matematis (mathematical thinking) sebagai melaksanakan kegiatan atau proses matematika (doing math) atau tugas matematis (mathematical task). Hal senada juga disampaikan Devlin's Angel dalam Siegel (2010) bahwa berpikir matematis adalah cara melihat sesuatu, baik dari segi numeriknya, struktur, logika dan menganalisa pola yang mendasarinya

Selanjutnya Del Mas dalam Sumarmo (2010) juga menjelaskan bahwa pengertian berpikir matematis dipandang lebih luas cakupannya dibandingkan dengan penalaran matematis atau dapat dikatakan berpikir matematis memuat komponen penalaran matematis.

Proses berpikir matematis menurut Scusa (2008) didasarkan pada lima kemampuan utama, yakni: 1) Representasi, 2) Penalaran dan Bukti, 3) Komunikasi, 4) Pemecahan Masalah, dan 5) Koneksi. Hal ini juga sesuai dengan standar (NCTM, 2000) yang menyatakan bahwa berpikir matematis diklasifikasikan dalam lima kompetensi utama dengan indikator: 1) pemahaman matematis, 2) pemecahan masalah matematis, 3) penalaran matematis, 4) koneksi matemati, dan 5) komunikasi matematis.

Ditinjau dari kedalaman atau kekomplekan kegiatan matematika yang terlibat, berpikir matematis dapat digolongkan dalam dua jenis, yaitu berpikir matematis tingkat rendah (low order mathematical thingking) dan berpikir matematis tingkat tinggi (High order mathematical thinking). Menurut Thomson (2008) bahwa berpikir matematis tingkat rendah seringkali dicirikan dengan mengingat kembali informasi atau aplikasi konsep atau pengetahuan. Sama halnya Schmalz (dalam Thomson, 1992) juga mengemukakan bahwa tugas-tugas berpikir matematis tingkat rendah memerlukan siswa untuk mengingat sebuah fakta, melakukan sebuah operasi yang sederhana, atau menyelesaikan suatu bentuk masalah yang rutin. Secara umum berpikir matematis tingkat rendah dicirikan sebagai pemecahan masalah yang bekerja dalam situasi-situasi dan konteks yang dikenal atau menerapkan algoritma yang telah dikenal siswa. 
Contoh soal berpikir matematis tingkat rendah:

Rafi membaca buku cerita anak-anak berisi 507 halaman, dia telah membaca 127 halaman. Jika sehari Rafi mampu membaca 20 halaman, maka berapa hari lagi dia membaca buku cerita itu?

Soal di atas tidak memerlukan pemikiran dan analisis yang mendalam, dan dapat diselesaikan oleh siswa dengan mudah.

Sebaliknya Resnick (dalam Thomson, 1992) mencirikan berpikir matematis tingkat tinggi sebagai non-algoritma. Begitu juga Stein dan Lane masih dalam (Thomson, 1992) menjelaskan berpikir matematis tingkat tinggi sebagai pemakaian kompleks, berpikir non algoritma untuk menyelesaikan suatu tugas yang bukan sesuatu yang dapat diprediksi, diperlukan justifikasi dan penjelasan.

Contoh soal berpikir matematis tingkat tinggi:

Faruq berjalan kaki dari lokasi rumah ke sekolah dengan kecepatan $3 \mathrm{~km} / \mathrm{jam}$. Jarak rumah ke sekolah adalah $4 \mathrm{~km}$. Faruq berangkat dari rumah pada pukul 07.00 WIB. Setelah berjalan kaki selama 30 menit, ia beristirahat selama 5 menit. Kemudian ia melanjutkan perjalanannya kembali dengan kecepatan yang sama. Pada pukul 07.50, Alfath berangkat dari rumah menuju sekolah dengan mengendarai sepeda yang berkecepatan $12 \mathrm{~km} / \mathrm{jam}$. Pada jarak berapa Faruq bertemu dengan Alfath?

Soal di atas tidak bisa diselesaikan secara langsung, sebelumnya siswa perlu memahami soal, menganalisa kemudian baru merencanakan penyelesaian. Berpikir matematis tingkat rendah dan tingkat tinggi bisa dilatihkan mulai dari tingkat sekolah dasar. Sedangkan berdasarkan kekomplekan materi dan tingkat abstraksinya, berpikir matematika dapat dibedakan menjadi dua bagian, yaitu Elementary Mathematical Thinking (EMT) dan Advanced Mathematical Thinking (AMT).

Terdapat perbedaan yang mendasar antara EMT dengan AMT, yaitu kekomplekannya, salah satu contoh konsep matematika tingkat lanjut adalah ring dan grup pada aljabar abstrak. Secara kuantitatif AMT lebih membutuhkan kemampuan yang lebih dalam merefleksi, merepresentasi dan mengabstraksi dibandingkan EMT, AMT lebih menekankan pada pembuktian. Sedangkan secara kualitatif terjadi transisi dari melukiskan ke mendefinisikan dan dari meyakinkan ke membuktikan secara logis. Selanjutnya Masonet. et. al (dalam Tall, 2002) menggambarkan proses verifikasi dalam AMT pada tiga tingkatan:1) meyakinkan diri sendiri, 2) meyakinkan teman 3) meyakinkan musuh. Dalam meyakinkan diri sendiri mengapa suatu pernyataan bernilai benar, dalam menyakinkan teman disertai dengan argumen yang terorganisasi secara koheren, dan dalam meyakinkan musuh disertai dengan argumen yang terorganisasi secara koheren, dianalisis dan diperhalus sehingga siap untuk dikritisi. Menurut Tall (2002) banyak aktivitas yang terjadi dalam proses AMT ini juga terjadi dalam pemecahan masalah matematika sekolah 
dasar dan sekolah menengah, misalnya proses representasi (representasi objek dunia nyata, representasi konkrit) tetapi definisi, proses abstraksi dan pembuktian formal merupakan salah satu faktor yang membedakan dengan AMT.

Contoh soal kemampuan elementary mathematical thinking:

Misalkan $\mathrm{f}: \mathrm{A} \rightarrow \mathrm{B}$ dengan $\mathrm{A}=\{1,2,3,4\}$ dan $\mathrm{B}=\{3,6,9,12\}$, berikan contoh fungsi satu-satu dari A ke B dalam bentuk diagram venn dan pasangan terurut.

Contoh soal kemampuan advanced mathematical thinking:

Misalkan $\mathrm{f}: \mathrm{A} \rightarrow \mathrm{B}$ dengan $\mathrm{f}(\mathrm{x})=2 \mathrm{x}$, buktikan bahwa f fungsi satu-satu.

Pada elementary mathematical thinking siswa meyakinkan kebenaran suatu konsep dengan memberikan contoh fungsi satu-satu, sementara pada advanced mathematical thinking siswa mampu membuktikan fungsi satu-satu secara formal. Untuk menghadapi era informasi sekarang ini dituntut mahasiswa memiliki kemampuan advanced mathematical thinking.

Berdasarkan penjelasan di atas, yang dimaksud dengan mathematical thinking pada makalah ini adalah cara melihat sesuatu, baik dari segi numeriknya, struktur, logika dan menganalisa pola yang mendasarinya.

\subsubsection{Disposisi Berpikir}

Menurut Ennis (1996) mendefinisikan sebuah disposisi berpikir sebagai sebuah kecenderungan untuk melakukan sesuatu dalam kondisi tertentu. Berdasarkan pengertian dan definisi yang diberikan Ennis di atas, dapat disimpulkan bahwa disposisi berpikir kritis adalah sebuah kecenderungan untuk bersikap, bertindak, atau bertingkah laku menuju pola-pola khusus dari tingkah laku berpikir kritis jika diberikan suatu kondisi atau perlakuan tertentu.

Definisi di atas menunjukkan bahwa disposisi merupakan suatu kecenderungan untuk bersikap, bertindak, atau bertingkah laku terhadap suatu perlakuan tertentu. Kecenderungan-kecenderungan tersebut secara alami membentuk pola-pola sikap atau tingkah laku tertentu pada diri seseorang yang dapat menjadi 'atribut' untuk orang tersebut. Misalnya, seseorang yang cenderung marah atau tersinggung apabila padanya diberi suatu kritik maka akan memberi gambaran pada orang lain mengenai disposisinya yang cepat marah atau tersinggung meskipun ia tidak dalam kondisi tersebut atau ia tidak sedang dikritik.

Sementara itu, Ritchhart dalam Sumarmo (2010) pengertian disposisi itu sendiri merupakan "perkawinan" antara kesadaran, motivasi, inklinasi, dan kemampuan yang diamati. Sementara itu Gavriel Salomon (dalam Tishman dan Andrade, 2009) mendefinisikan disposisi sebagai kumpulan sikap-sikap pilihan dengan kemampuan yang memungkinkan sikap-sikap pilihan tadi muncul dengan cara tertentu. Menurut 
Tishman, dkk. Disposisi berpikir adalah kecenderungan perilaku intelektual dalam upaya mengidentifikasi sifat dari pola pikir. Pengertian disposisi berpikir pada makalah ini adalah kecenderungan seseorang dalam bersikap, bertindak, dan berperilaku positif dalam upaya mengidentifikasi sifat dari pola pikir.

\subsubsection{Disposisi Matematis}

Menurut Sumarmo (2010) disposisi matematis yaitu keinginan, kesadaran, kecenderungan dan dedikasi yang kuat pada diri siswa atau mahasiswa untuk berpikir dan berbuat secara matematis. Dengan cara yang positif, Polking dalam Sumarmo (2010), mengemukakan bahwa disposisi matematis menunjukkan (1) rasa percaya diri dalam menggunakan matematika, memecahkan masalah, memberi alasan dan mengkomunikasikan gagasan, (2) fleksibilitas dalam menyelidiki gagasan matematis dan berusaha mencari metoda alternatif dalam memecahkan masalah; (3) tekun mengerjakan tugas matematika; (4) minat, rasa ingin tahu (curiosity), dan daya temu dalam melakukan tugas matematika; (5) cenderung memonitor, merepleksikan performance dan penalaran mereka sendiri; (6) menilai aplikasi matematika ke situasi lain dalam matematika dan pengalaman sehari-hari; (7) apresiasi (appreciation) peran matematika dalam kultur dan nilai, matematika sebagai alat, dan sebagai bahasa. Senada dengan pendapat di atas, (NCTM, 2000) mengemukakan bahwa disposisi matematis menunjukkan: rasa percaya diri, ekspektasi dan metakognisi, gairah dan perhatian serius dalam belajar matematika, kegigihan dalam menghadapi dan menyelesaikan masalah, rasa ingin tahu yang tinggi, serta kemampuan berbagi pendapat dengan orang lain.

Berdasarkan beberapa definisi di atas, maka pengertian disposisi matematis pada makalah ini adalah kecenderungan sikap positif serta kebiasaan untuk melihat matematika sebagai sesuatu yang logis, dan berguna.

\subsubsection{Disposisi Berpikir Kreatif Matematis}

Pengertian disposisi berpikir kreatif matematis tidak ada yang mendefinisikan secara jelas, namun berdasarkan definisi disposisi berpikir dan disposisi matematis, disposisi berpikir kreatif matematis pada makalah ini adalah kecenderungan seseorang bersikap dan berpikir kreatif. Ada beberapa hasil teori yang merumuskan karakteristik dari disposisi berpikir kreatif, antara lain disusun oleh: Munandar, dan Evans. Skala disposisi berpikir kreatif disusun berdasarkan aspek-aspek perilaku kreativitas yang dikemukakan oleh Munandar (1999). Menurut Munandar, aspek kreativitas terdiri dari :

1) Keterampilan berpikir lancar (Fluency), indikatornya:

a) mengajukan banyak pertanyaan.

b) menjawab dengan sejumlah jawaban jika ada pertanyaan.

c) lancar mengungkapkan gagasan-gagasannya.

d) bekerja lebih cepat dan melakukan lebih banyak daripada anak-anak lainnya. 
e) dapat dengan cepat melihat kesalahan atau kekurangan pada suatu objek atau situasi.

2) Keterampilan berpikir luwes (Fleksibel), indikatornya:

a) memberikan aneka ragam penggunaan yang tidak lazim terhadap suatu objek.

b) memberikan macam-macam penafsiran (interpretasi) terhadap suatu gambar, cerita, atau masalah.

c) menerapkan suatu konsep atau asas dengan cara yang berbeda-beda.

d) memberikan pertimbangan terhadap situasi yang berbeda dari yang diberikan orang lain.

e) dalam membahas atau mendiskusikan suatu situasi selalu mempunyai posisi yang berbeda atau bertentangan dari mayoritas kelompok.

f) jika diberikan suatu masalah biasanya memikirkan macam-macam cara yang berbeda-beda untuk menyelesaikannya.

g) menggolongkan hal-hal menurut pembagian (kategori yang berbeda-beda).

h) mampu mengubah arah pemikiran.

3) Keterampilan berpikir orisinal, indikatornya:

a) memikirkan masalah-masalah atau hal-hal yang tidak terpikirkan oleh orang lain.

b) mempertanyakan cara-cara yang lama dan berusaha memikirkan cara-cara baru.

c) memilih a-simetri dalam membuat gambar atau desain.

d) memilih cara berpikir yang lain dari yang lain.

e) mencari pendekatan yang baru dari stereotip.

f) setelah membaca atau mendengar gagasan-gagasan, bekerja untuk menemukan penyelesaian yang baru.

g) lebih senang mensintesa dari pada menganalisis sesuatu.

4) Keterampilan memperinci (Mengelaborasi), indikatornya:

a) mencari arti yang lebih mendalam terhadap jawaban atau pemecahan masalah dengan melakukan langkah-langkah yang terperinci.

b) mengembangkan atau memperkaya gagasan orang lain.

c) mencoba atau menguji detil-detil untuk melihat arah yang akan ditempuh.

d) mempunyai rasa keindahan yang kuat sehingga tidak puas dengan penampilan yang kosong atau sederhana.

e) menambahkan garis-garis, warna-warna, dan detil-detil (bagian-bagian) terhadap gambarnya sendiri atau gambar orang lain.

5) Keterampilan menilai (Mengevaluasi), indikatornya:

a) memberi pertimbangan atas dasar sudut pandangnya sendiri.

b) menentukan pendapat sendiri mengenai suatu hal.

c) menganalisis masalah atau penyelesaian kritis dengan selalu menanyakan "mengapa?".

d) mempunyai alasan yang dapat dipertanggungjawabkan untuk mencapai suatu keputusan. 
e) merancang suatu rencana kerja dari gagasan-gagasan yang tercetus.

f) pada waktu tertentu tidak menghasilkan gagasan-gagasan tetapi menjadi peneliti atau penilai yang kritis.

g) menentukan pendapat dan bertahan terhadapnya.

6) Rasa ingin tahu, indikatornya:

a) mempertanyakan segala sesuatu.

b) senang menjajaki buku-buku, peta-peta, gambar-gambar, dan sebagainya untuk mencari gagasan-gagasan baru.

c) tidak membutuhkan dorongan untuk menjajaki atau mencoba yang belum dikenal.

d) menggunakan semua panca inderanya untuk mengenal.

e) tidak takut menjajaki bidang-bidang baru.

f) ingin mengamati perubahan-perubahan dari hal-hal atau kejadian-kejadian.

g) ingin bereksperimen dengan benda-benda mekanik.

7) Imajinatif, indikatornya:

a) memikirkan/membayangkan hal-hal yang belum pernah terjadi.

b) memikirkan bagaimana jika melakukan sesuatu yang belum pernah dilakukan orang lain.

c) meramalkan apa yang akan dikatakan atau dilakukan orang lain.

d) mempunyai firasat tentang sesuatu yang belum terjadi.

e) melihat hal-hal dalam suatu gambar yang tidak dilihat orang lain.

f) membuat cerita tentang tempat-tempat yang belum pernah dikunjungi atau kejadian-kejadian yang belum pernah dialami.

8) Merasa tertantang oleh kemajemukan, indikatornya:

a) menggunakan gagasan atau masalah-masalah yang rumit.

b) melibatkan diri dalam tugas-tugas yang majemuk.

c) tertantang oleh situasi yang tidak dapat diramalkan keadaannya.

d) mencari penyelesaian tanpa bantuan orang lain.

e) tidak cenderung mencari cara tergampang.

f) berusaha terus-menerus agar berhasil.

g) mencari jawaban-jawaban yang lebih sulit daripada menerima yang mudah.

h) senang menjajaki jalan yang lebih rumit.

9) Sifat berani mengambil resiko, indikatornya:

a) berani mempertahankan gagasan atau pendapatnya walaupun mendapat tantangan atau kritik.

b) bersedia mengakui kesalahan-kesalahannya.

c) berani menerima tugas yang sulit meskipun ada kemungkinan gagal.

d) berani mengajukan pertanyaan atau mengemukakan masalah yang tidak dikemukakan orang lain.

e) tidak mudah dipengaruhi orang lain.

f) melakukan hal-hal yang diyakini, meskipun tidak disetujui sebagian orang.

g) berani mencoba hal-hal baru. 
h) berani mengakui kegagalan dan berusaha lagi.

10) Sifat menghargai, indikatornya:

a) menghargai hak-hak sendiri dan hak-hak orang lain.

b) menghargai diri sendiri dan prestasi sendiri.

c) menghargai makna orang lain.

d) menghargai keluarga, sekolah dan teman.

e) menghargai kebebasan tetapi tahu bahwa kebebasan menuntut tanggung jawab.

f) tahu apa yang betul-betul penting dalam hidup.

g) menghargai kesempatan-kesempatan yang diberikan.

h) senang dengan penghargaan terhadap dirinya."

Sedangkan menurut Evans (1991) aspek-aspek perilaku kreativitas adalah: awareness and sensitivity to problems, memory, fluency, flexibility, originality, selfdiscipline and persistence, adaptability, intellectual playfulness, humor, nonconformity, tolerance for ambiguity, self confidence, skepticism, dan intelligence.

\subsection{Pendekatan APOS}

Menurut Suryadi (2012) teori APOS adalah sebuah teori konstruktivisme tentang bagaimana seseorang belajar suatu konsep matematika. Begitu juga Nurlalelah (2009) menyatakan bahwa dasar filosofi teori APOS adalah konstruktivisme sosial. Pembelajaran dengan menggunakan teori APOS menekankan pada perolehan pengetahuan melalui konstruksi mental. Menurut Suryadi (2012) konstruksi mental dalam konteks teori APOS adalah terbentuknya aksi, yang direnungkan menjadi proses, selanjutnya dirangkum menjadi objek, objek dapat diuraikan kembali menjadi proses. Aksi, proses, dan objek dapat diorganisasi menjadi suatu skema, yang selanjutnya disingkat menjadi APOS.

Berikut pengertian Aksi, Proses, Objek, dan skema menurut M. Asiala (1997) dan Suryadi (2012).

\section{Aksi (action):}

Menurut M. Asiala, et al. (1997) An action is a transformation of mathematical objects that is performed by an individual according to some explicit algorithm and hence is seen by the subject as externally driven. Sama halnya dengan pengertian yang dinyatakan Suryadi (2012) bahwa aksi adalah suatu transformasi objek-objek mental untuk memperoleh obyek mental lainnya. Selanjutnya Suryadi juga menyatakan bahwa seseorang dikatakan mengalami suatu aksi apabila orang tersebut memfokuskan proses mentalnya pada upaya untuk memahami suatu konsep yang diberikan. Untuk lebih jelasnya tentang penjelasan tentang konsepsi aksi, diberikan sebuah ilustrasi mengenai konsep grup. Seseorang yang belum mampu menginterpretasikan sesuatu sebagai suatu grup, kecuali jika diberikan sebuah 
himpunan hingga terhadap sebuah operasi sehingga mampu menentukan apakah himpunan hingga itu sebuah grup, dapat dinyatakan seseorang telah memiliki kemampuan untuk melakukan aksi atas grup tersebut.

\section{Proses (Process):}

Menurut Asiala, et al. (1997) sebagai berikut: When the individual re-acts on the action and constructs an internal operation that performs the same transformation then we say that the action has been interiorized to a process. Senada dengan Asiala, et al., Suryadi (2012) juga menyatakan bahwa ketika suatu aksi diulangi, dan kemudian terjadi refleksi atas aksi yang dilakukan, maka selanjutnya akan masuk ke dalam fase proses. Berbeda dengan aksi yang dapat terjadi melalui manipulasi benda atau sesuatu yang bersifat konkrit, proses terjadi secara internal di bawah kontrol individu yang melakukannya. Seseorang dikatakan mengalami suatu proses tentang sebuah konsep, apabila berpikirnya terbatas pada ide matematik yang dihadapi serta ditandai dengan munculnya kemampuan untuk melakukan refleksi terhadap ide matematika tersebut. Misalnya pada konsep grup, seseorang dikatakan mengalami proses apabila telah mampu memanipulasi beberapa himpunan dan terhadap operasi sebarang, dapat dinyatakan telah memiliki kemampuan untuk melakukan proses pada konsep grup tersebut.

\section{Objek (object)}

Menurut Asiala, et al. (1997) objek didefinisikan sebagai berikut: When it becomes necessary to perform actions on a process, the subject must encapsulate it to become a total entity, or an object. In many mathematical operations, it is necessary to deencapsulate an object and work with the process from which it came. Begitu juga Suryadi (2012) menyatakan bahwa seseorang dikatakan telah memiliki konsepsi objek dari suatu konsep matematika, apabila ia telah mampu memperlakukan idea atau konsep tersebut sebagai sebuah objek kognitif yang mencakup kemampuan untuk melakukan aksi atas objek tersebut, serta memberikan alasan atau penjelasan tentang sifat-sifatnya. Selain itu individu tersebut juga telah mampu melakukan penguraian kembali suatu ojek menjadi proses sebagai mana asalnya pada saat sifatsifat dari objek yang dimaksud akan digunakan. Hal ini dapat di ilustrasikan pada konsep grup, seseorang dikatakan telah memiliki konsepsi objek pada konsep grup apabila ia telah mampu melakukan pengelompokan grup serta mampu menjelaskan sifat-sifat dari masing-masing grup.

\section{Skema (Schema):}

Menurut Asiala,et al. (1997) skema adalah:A schema is a coherent collection of processes, objects and previously constructed schemas, that is invoked to deal with a mathematical problem situation. As with encapsulated processes, an object is created when a schema is thematized to become another kind of object which can also be de-thematized to obtain the original contents of the schema. Sama halnya, Suryadi (2012) menyatakan bahwa sebuah skema dari suatu materi matematika 
tertentu adalah suatu koleksi aksi, proses, objek, dan skema lainnya yang saling terhubung sehingga membentuk suatu kerangka kerja saling terkait di dalam pikiran seseorang. Indikator seseorang telah memiliki skema adalah apabila orang tersebut telah memiliki kemampuan untuk mengkonstruk contoh-contoh suatu konsep matematika sesuai dengan sifat-sifat yang dimiliki konsep tersebut. Pada Konsep grup, seseorang dikatakan telah memiliki konsepsi skema apabila ia telah mampu mengkonstruk contoh-contoh dari grup sesuai dengan sifat-sifat yang dimiliki konsep grup.

Menurut Asiala (dalam Arnawa, 2006) Ada beberapa hal yang dapat dipandang sebagai karakteristik pembelajaran berdasarkan teori APOS, yaitu pembelajarannya meliputi/mengikutsertakan: (1) pengetahuan dikonstruksi mahasiswa melalui konstruksi mental APOS, (2) menggunakan komputer, (3) mahasiswa belajar dalam kelompok kecil, (4) menggunakan siklus ACE (activity, class discussion, excercise). Berikut ini adalah deskripsi untuk Siklus ACE (Activities, Class discussion, and Exercise). Activities, merupakan aktivitas mahasiswa memperoleh pengalaman yang berhubungan dengan ide-ide matematis yang akan dikembangkan di dalam perkuliahan. Aktivitas ini biasanya dilakukan di laboratorium komputer, aktivitas di laboratorium akan merupakan bekal bagi mahasiswa yang bersangkutan agar dapat berperan aktif dalam diskusi kelas. Class discussion, diskusi kelas dilakukan secara berkelompok, mereka mengerjakan tugas-tugas yang berhubungan dengan aktivitas mahasiswa di laboratorium. Dosen sebagai fasilitator terlibat dalam diskusi tiap-tiap kelompok sehingga mahasiswa diberi kesempatan untuk melakukan refleksi terhadap tugas-tugas yang sudah dikerjakannya. Dalam diskusi kelas dosen berusaha untuk meninjau tentang apa yang dipikirkan mahasiswa Asiala et al., (1997). Selanjutnya melalui interaksi antar mahasiswa diharapkan terjadi pertukaran pengalaman belajar berbeda sehingga aksi mental dapat terus berlanjut sesuai dengan yang diharapkan. Aktivitas seperti ini terus belanjut sampai mahasiswa memiliki kemampuan untuk melakukan refleksi terhadap aksi yang telah dilakukan, sehingga mahasiswa dapat mencapai tahap perkembangan potensial.

Menurut Suryadi (2012) salah satu landasan yang digunakan pada proses pembentukan skema pada konstruksi mental APOS adalah teori ZPD dari Vygotsky. Perkembangan kemampuan kognitif anak terbagi ke dalam dua tahap yaitu tahap perkembangan aktual dan tahap perkembangan potensial. Untuk mencapai tahap perkembangan potensial dibutuhkan bantuan orang dewasa atau orang lain yang lebih mampu, hal ini dapat terjadi pada saat diskusi kelas. Exercise, Pada siklus ini, mahasiswa diberikan latihan-latihan untuk dikerjakan secara berkelompok, sebagian besar dari latihan-latihan ini diharapkan dikerjakan di luar kegiatan kelas untuk memperkuat ide yang dibangun mahasiswa Asiala et al. (1997). 


\section{III.Penutup}

Pada pembelajaran yang menggunakan pendekatan APOS dengan siklus ACE dapat menumbuhkan sikap positif siswa/mahasiswa terhadap matematika serta mampu membiasakannya dalam berpikir matematis dan mampu meningkatkan disposisi berpikir kreatif matematis siswa/mahasiswa. Hal ini sesuai dengan hasil penelitian Nurlaelah (2009) yang menggunakan teori APOS, ditemukan bahwa mahasiswa calon guru yang menggunakan pendekatan APOS untuk mencapai kreativitas matematis lebih baik dari pembelajaran konvensional.

\section{DAFTAR PUSTAKA}

Arnawa, M. (2006). Meningkatkan kemampuan Pembuktian Mahasiswa dalam Aljabar Abstrak melalui Pembelajaran Berdasarkan Teori APOS. Disertasi pada Universitas Pendidikan Indonesia: Tidak Diterbitkan

Depdiknas. (2004). Kurikulum 2004 Standar Kompetensi Mata Pelajaran Matematika Sekolah Menengah Atas (SMA) dan Madrasah Aliyah (MA). Jakarta: Depdiknas.

Ennis, R.H. (1996). Critical Thinking. Toronto: Prentice-Hall, Inc.

Evans, J.R. (1991). Creative Thinking in the Decision and Management Sciences. Cincinnati, Ohio: South-Western Publishing Co.

M. Asiala, Cottrill, J., Dubinsky, Ed., \& Schwingendorf. (1997). "The development of students' graphical understanding of the derivative". Journal of Mathematical Behavior, 16(4), 399-431.

Munandar, S.C. Utami. (1999). Mengembangkan Bakat dan KreativitasAnak Sekolah. Petunjuk Bagi Para Guru dan Orang Tua. Jakarta.: PT Gramedia Widiasarana Indonesia.

National Council of Teachers of Mathematics. (2000). Principles and Standars for School Mathematics. Reston, V.A: National Council of Teachers of Mathematics

Nurlaelah, E. (2009). Pencapaian Daya dan Kreativitas Matematik Mahasiswa melalui Pembelajaran Berdasarkan Teori APOS. Disertasi pada Universitas Pendidikan Indonesia: Tidak Diterbitkan

Sabandar, J. (2008). Berpikir Reflektif. Makalah disampaikan pada Seminar Nasional Pendidikan Matematika Program Studi Pendidikan Matematika FKIP Universitas Riau di Pekanbaru pada tanggal 5 Februari 2008

Sagala, S. (2003). Konsep dan Makna Pembelajaran. Bandung: Alfabeta.

Scusa, Toni. (2008) "Five Processes of Mathematical Thinking". Summative Projects for MA Degree. Paper 38.http://digitalcommons.unl.edu/mathmidsummative/38

Siegel, Harvey. (2010). What (Good) Are Thinking Dispositions?. International Journal Of Mathematical Education

Sumarmo. (2010). Berpikir dan Disposisi Matematis: Apa, Mengapa, dan Bagaimana dikembangkan pada Peserta Didik. Makalah.Tidak Dipublikasikan. 
Suryadi, D. (2012). Membangun Budaya Baru dalam Berpikir Matematika.Bandung: Rizqi Press

Tall, D. (2002). Advanced Mathematical Thinking. Boston: Kluwer Academic Publisher

Thompson, A. G. (1992). Teachers' Belief and Conceptions: A Synthesis of The Research. Dalam D. A.Grouws (ed). Handbook of Research on Mathematics Teaching and Learning. New York: Macmillan. 127-143. 